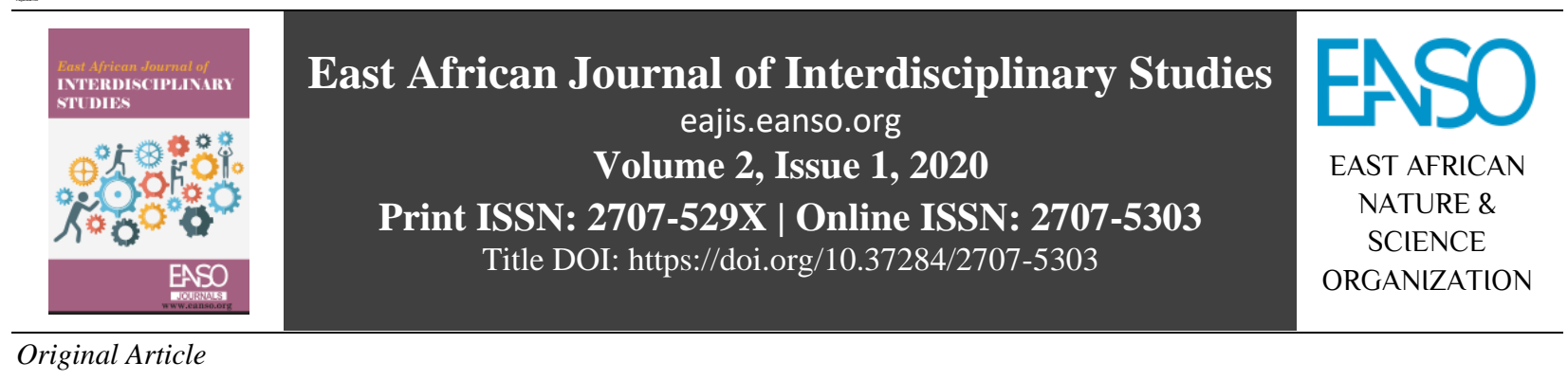

\title{
Human Resource Practices and Quality Assurance Among Teachers in Public Secondary Schools in the Central Region, Uganda
}

\author{
Mary Anyango $^{1 *}$, Regis Zombeire Kamaduuka ${ }^{2}$, \& Dr. Goretti Kaahwa ${ }^{2}$ \\ ${ }^{1}$ Kyambogo University, P. O. Box 1, Kyambogo, Kampala. \\ *Author for Correspondence Email: maryoyonyeko@gmail.com \\ * ORCID: https://orcid.org/0000-0003-2337-0541
}

Article DOI: https://doi.org/10.37284/eajis.2.1.175

\section{Date Published: ABSTRACT}

26 June 2020 The study aimed at establishing the influence of human resource practices on quality assurance among secondary school teachers in the central region of

Keywords: Uganda. It was guided by the objective of establishing the relationship between on-job training, off-job training, and promotions on quality assurance among

Teachers, teachers in the central region of Uganda. It was a desktop content review of Human Resource, literature journal articles and research dissertations that was thematically Development, analysed. The findings obtained showed that to a great extent, the provision of Practices, on-job training, off-job training and promotions to teachers enhances the Quality Assurance,

Training,

Public Schools,

Central Uganda. quality assurance in secondary schools. Thus, it was concluded that the professional development of teachers is a critical aspect that all administrators should not neglect. Consequently, it was recommended that junior teachers should be assigned to senior teachers who should act as coaches, supervisors and mentors. Also, off-job training policies should be developed to enhance teachers' teaching skills and once trained; the teachers have to be promoted.

\section{APA CITATION}

Anyango, M., Kamaduuka, R., \& Kaahwa, G. (2020). Human Resource Practices and Quality Assurance Among Teachers in Public Secondary Schools in the Central Region, Uganda. East African Journal of Interdisciplinary Studies, 2(1), 39-48. https://doi.org/10.37284/eajis.2.1.175

\section{CHICAGO CITATION}

Anyango, Mary, Regis Kamaduuka, and Goretti Kaahwa. 2020. "Human Resource Practices and Quality Assurance Among Teachers in Public Secondary Schools in the Central Region, Uganda”. East African Journal of Interdisciplinary Studies 2 (1), 39-48. https://doi.org/10.37284/eajis.2.1.175.

\section{HARVARD CITATION}

Anyango, M., Kamaduuka, R. and Kaahwa, G. (2020) "Human Resource Practices and Quality Assurance Among Teachers in Public Secondary Schools in the Central Region, Uganda", East African Journal of Interdisciplinary Studies, 2(1), pp. 39-48. doi: 10.37284/eajis.2.1.175. 


\section{IEEE CITATION}

M. Anyango, R. Kamaduuka, and G. Kaahwa, "Human Resource Practices and Quality Assurance Among Teachers in Public Secondary Schools in the Central Region, Uganda”, EAJIS, vol. 2, no. 1, pp. 39-48, Jun 2020.

\section{MLA CITATION}

Anyango, Mary, Regis Kamaduuka, and Goretti Kaahwa. "Human Resource Practices and Quality Assurance Among Teachers in Public Secondary Schools in the Central Region, Uganda”. East African Journal of Interdisciplinary Studies, Vol. 2, no. 1, Jun 2020, pp. 39-48, doi:10.37284/eajis.2.1.175.

\section{INTRODUCTION}

Quality teaching by teachers has remained a serious challenge to educational institutions across the world. Teachers' quality has continued to be doubted in the execution of their teaching roles. In this paper, it is assumed that the failure to provide professional development would be responsible for this poor-quality teaching. Thus, the definitions, literature related to major themes, methods and implications are given. Human resource practices will refer to the continuous process from which skills and abilities are offered to teachers to match with the responsibilities at their professional environments (Aslam, 2013).

World over, teachers are expected to be maintaining a high quality of teaching in their profession to meet the set standard in a country. According to MoES (2017) report, quality assurance in public secondary education is still poor in Uganda, especially in the central region in terms of teachers' competence, poor assessment methods, inadequate instructional materials and poor learning infrastructures. This would be mitigated when the human resource quality, and examinations assessments, as well as adequate improvement of infrastructures (Rahman et al., 2011). Looney and Hannah (2017) observed that internal mechanisms might include schools' self-evaluation through classroom-based students' assessments as part of an integrated system. Meanwhile, Ayani (2010) identified that the issue of quality assurance in education, noting it had become a matter of concern for government institutions and secondary schools to meet the expectations in teaching and learning. However, these expectations were not isolated from ascertaining whether they involve teaching, assessment and the appropriate use of resources. The study was guided by the Human Capital Theory developed by Becker Gary (1964).
According to this theory, human beings are considered to be vital resources that need to be invested in mainly through training to boost their productivity on the job (Morozoua, 2016). Also, the theory has it that an educated labour force is an efficient system since it has skills, knowledge and values required on the job. Basing on this theory, it is assumed in this study that teachers in selected secondary schools in Kampala District are a vital resource that must be invested in mainly through training by offering them opportunities to attend conferences, study seminars, workshops, coaching them and through allowing them to acquire study leaves. Once these are offered to teachers, quality assurance is guaranteed. The opposite will mean that the reverse is true. Further, the study was also guided by the systems theory of management developed by Von Bertalanffy in 1958, as cited by Mullins (2010).

The systems theory states that organisations and institutions are composed of three interacting parts; the inputs, the process and the outputs. In the inputs, we have human resources, facilities and equipment. It is assumed that a teacher is one of the inputs. Once these teachers are developed, they will exercise their duties diligently at work. Thus, they have to be provided with human resource professional development on-job training, off-job training and promotions. Once this is done, it is likely that these teachers will work competently, handle school human resources, teach effectively, assess the learners as required and give feedback. Human resource practices are defined by Aslam (2013) as a continuous process from which skills and abilities are offered to a teacher to match with the responsibilities of the environment and the profession. Yet Chukuma and Ofojebe (2015) defined it as a process of improving and increasing capacities of staff through access to education training opportunities inside and outside the job. 
In this study, professional development of teachers will lean on on-job training (like coaching, mentoring and training) and off-job training (like upgrading, workshops conferences and seminars). It will also deal with promotions involving promotions and transfers upward. According to Hamad, Shume and Hamadi (2011), quality assurance (Dependent Variable) is defined as excellence or fit for purpose where quality fulfils the perceived requirements of stakeholders. Hence, quality assurance in education is described as the totality of features and characteristics of service that bear on its ability to satisfy stated or implied needs and set standards. In this study, it will mean the quality of teaching with preparations, schemes of work, lesson plans and applying effective teaching methods. It will also entail teachers assessing learners by setting examinations, timely administering, giving of feedback, and fair grading of learners. It will finally involve quality preparation by using resources like computers, boards, books and equipment's used in teaching with adequate infrastructures (classrooms and sanitary facilities).

The study focused on public secondary schools in the Central Regions of Uganda dealing with the problem of quality assurance among teachers which is determined now and again. According to a report produced at KCCA (2017), it was revealed that quality assurance in these secondary schools was going down, teachers' handling of human resources was indicated as poor in students' evaluation, examinations and handling of teaching resources were ineffective. Skills such as basic literacy and communication, which are essential in one's teaching process, were equally low.

\section{Problem Statement}

Globally, quality assurance in higher education institutions has been an issue of great concern. Materu (2015) revealed that much effort is now made to ensure that quality assurance remains at all education level. This view resonates that of Ayani (2011) who stated that the quest for quality improvement in education service delivery is helpful in ensuring effective resource input, control refining the standards of output in order to meet set goals and satisfy public accountability in Uganda. The government through the Ministry of Education and Sports has laboured to put up regular inspections like subject assessments (MoES, 2017). This is made to ensure that teachers' quality in teaching preparations, writing schemes of work, writing lesson plans and appropriate teaching methods are realised. Despite these efforts made, teachers' quality assurance in selected secondary schools in the central region has remained below expectations. Teachers haphazardly prepare, make lesson plans, teach diligently, examine and assess learners' work. Also, the quality of teachers using resource books, computers, textbooks and classrooms, as well as sanitary facilities, were isolated to be poor. If this situation remains the way it is, quality assurance will continue to worsen at the expense of quality secondary school education. It is on this account that this study was carried out to establish the relationship between human resource development practices and quality assurance among teachers in public secondary schools in the central region of Uganda.

\section{Objectives of the Study}

(i) To find out the influence of human resource practices on quality assurance among teachers in secondary schools in the central region of Uganda.

(ii) To examine the impact of on-job work station human resource practices on quality assurance among teachers in the central region of Uganda.

(iii) To establish the relationship between off-job work station human resource practices and quality assurance among teachers in the central region of Uganda.

(iv) To establish the relationship between promotions at work station and quality assurance among teachers in the central region of Uganda. 


\section{CONCEPTUAL FRAMEWORK}

Figure 1: Conceptual Framework Showing the Relationship Between Human Resource Practices and Quality Assurance Among Secondary School Teachers

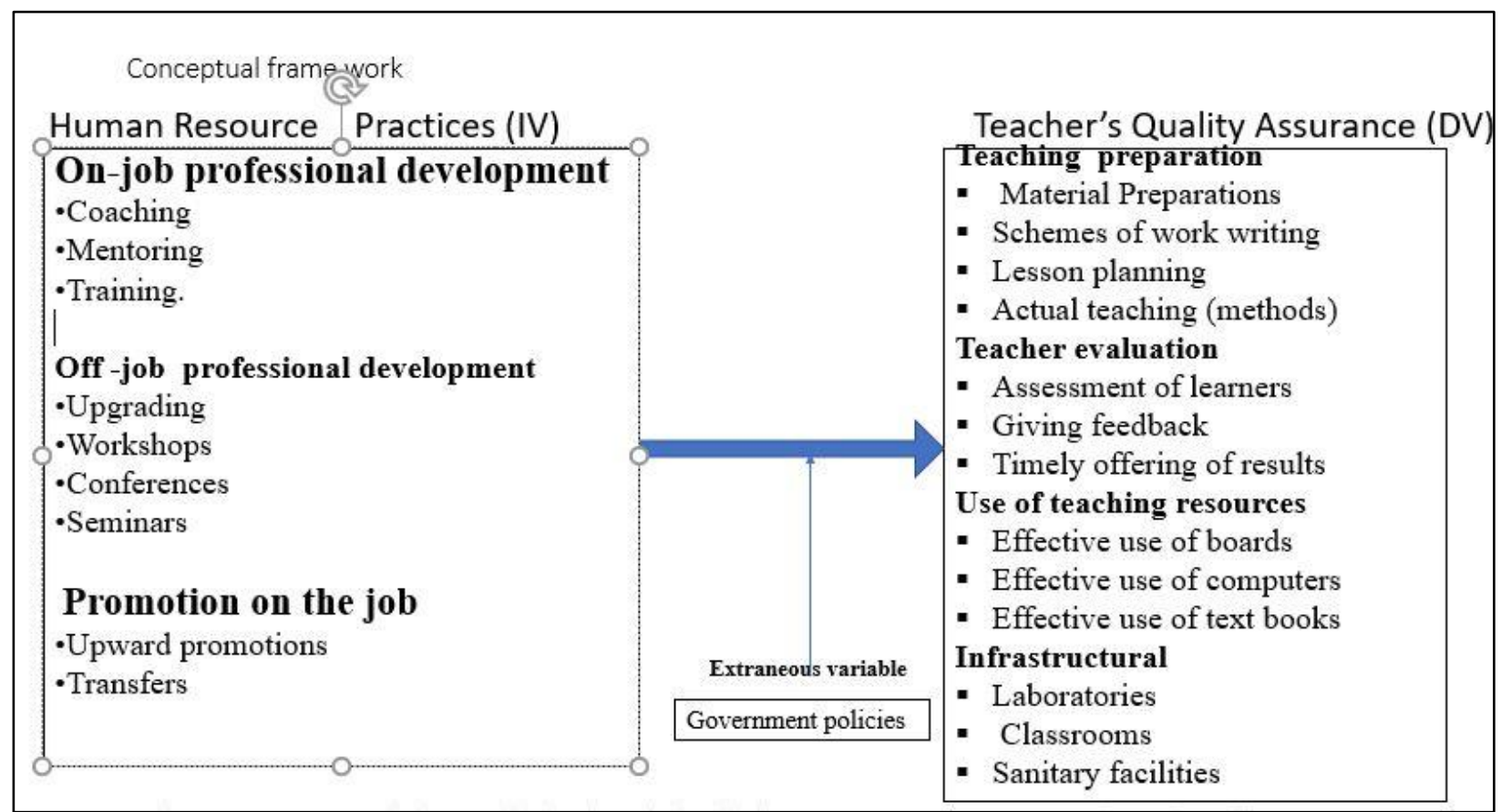

Source: Ayani (2011).

\section{LITERATURE REVIEW}

\section{On-Job Training and Quality Assurance Among Teachers in Secondary Schools}

Raed, Teir and Zhang (2016) identified human resource development practices, especially on-job training of teachers empowers them with critical skills necessary to gain a competitive advantage in the educational environment. Teachers were identified as learning by doing, which boosts their quality on the job. Whereas their study was carried out in the Asian world, this study is in Uganda, a developing country in Africa.

Rose and Reynolds (2006) observed that continuous professional development through organising internal seminars and workshops help in applying current teaching methodologies, opening up an inquisitive mindset and ending up achieving teaching ends, as a quality assurance measure. Mohan, Lingam and Chand (2017) studied teachers perceptions on the impact of professional development on learning and teaching in a developing nation and with use of semi-structured interviews as data collection methods established that offering teachers chances to collaborate, consult and work with close supervision of others enables them to develop skills and best practices needed in the teaching-learning process. Rahman et al. (2011) studied the relationship between the training of teachers and the effectiveness of teaching and revealed that there was a significant correlation between teachers in-service training and effective teaching. Seminars, workshops, coaching and mentoring organised on the job enhanced the performance of teachers significantly. Through the training, teachers would acquire new knowledge related to how to solve emerging problems.

Balyejjusa (2014) studied school contextual factors; talent management, teacher competency and student engagement in private secondary schools in Naddangira Zone, North of Wakiso District and established that teachers' talent management through provision of on-job training promotes skills that teachers are likely to transmit to learners. A favourable on-job training 
environment for teachers boosts their quality and the reverse is true.

Darling-Hammondi, Hyler and Gardner (2017) emphasised that teachers in program practice classroom routines acquire more collaborative skills learning with others as peers. Thus, this approach to the professional development of teachers focuses on teaching strategies with specific curriculum content which supports teachers learning in the classroom contexts. Once this is adopted, there is a high possibility that quality teaching of these teachers would enhance. The reverse is true. However, this review was from Texas, a developed world context slightly differing from Uganda a developing world.

On the other hand, Phillips (2008) studied professional development as a critical component of continuing teacher quality and established that mentoring development opportunities on the job are a critical component for changing the potential of workplace teaching. Through this approach, teachers would learn from experienced friends on how to teach and consequently ended up doing better on the job. Sylvester (2015) revealed that the human resource development of teachers, especially through offering inductions and close supervision by superiors improves the skills of teaching and the use of available resources in the school. However, this study was in higher education, while the proposed study will be targeting human resource development and quality assurance in the secondary school environment context.

Ogbodo (2012) emphatically stated that site-based training of teachers on-job allows them to acquire the necessary knowledge and develop the required skills which enhance quality assurance in schools. However, this was a theoretical assertion while the proposed study will be empirical. Meanwhile, Ayani (2011) in a study about teacher's professional development and quality assurance in Nigerian secondary schools showed that the experience one acquires on the job through mentoring, monitoring and supervisions were essential in boosting the quality assurance in these schools.

Olufunke and Joseph (2012) identified that inspection in the age-long known system of enforcing quality teaching is highly emphasised. This means monitoring and supervision once wellhandled ensures quality assurance in schools. Kramer (2015) identified that the quality of inservice teacher training varies drastically across countries. One good practice of in-service teachers training involves follow up visits to teachers' classrooms to provide ongoing support. Once this is done, quality assurance is maintained in schools. Teachers training needs follow up coaching often around a specific pedagogical technique. This study was mainly descriptive while the proposed study will be both descriptive and correlational. Balash et al. (2015) argued that teaching in HRM development programme takes quite a long time. Therefore, monitoring of the academic process should be carried out throughout the whole period of the provision of educational services. An important component of the teacher development programme is the quality assessment to the satisfaction of customers. However, in this study, aspects related to off-job training, promotions and quality assurance were not brought out.

\section{Off-Job Training and Quality Assurance Among Teachers}

Msuya (2016) studied the levels of job satisfaction of teachers in public secondary schools in Tanzania and established that young teachers were dissatisfied with the level at which off-job training was offered, lowering their potential to acquire jobrelated skills. This, in one way or the other, may affect the quality of their service delivery. Helmslorenz et al. (2016) studied teaching skills and transition smoothness of teachers educated in professional development schools in schools and revealed that teachers who had gone for professional training in professional development schools were more competent in terms of skills transfer during the teaching-learning process. Such teachers were revealed as able to apply relevant teaching methodologies, select appropriate content and assess students well. These in one way or the other portrayed high quality in teachers' delivery of their service.

Rahman et al. (2011) revealed that off-job training of teachers, especially through conferences, workshops, in-service training (especially through study leaves), allows teachers to acquire 
competencies abreast with the changing demands of the teaching profession. Consequently, they end up improving the quality of their teaching roles. This study was not carried out in a developing world context.

Kennedy (2016) investigated on how professional development improves teaching and with use of desktop review of articles established that online professional developments enhance the teaching quality of teachers through equipping them with current pedagogies needed in the modern world of teaching. This online professional training allows teachers to share knowledge with others in different parts of the world enabling quality enhancement to occur. However, in a country like Uganda, such online off-job training pedagogies may not be easy to adopt due to constraints of resources to support the same.

Similarly, Darling-Hammond et al. (2017) revealed that in one programme in Texas, teachers who developed small group professional development inquiry-based literacy, integrated the instructions of science classrooms to improve the quality of English teaching. However, in Uganda, it is not yet known whether a similar arrangement and how it impacts on the quality of teaching has been established. Sylvester (2015) in a study about human resource development in achieving quality assurance in higher education in Nigeria, revealed that human resource development through continuous off-job training offers job-related skills that enhance the quality of teaching in institutions of higher learning. However, this study did not indicate whether it used approaches and analysis techniques like Pearson's correlation coefficient index that this study will adopt. Ogbodo (2012), stressed that human capacity building hinges absolutely on education and teachers are the pivot of the education system. Teachers, being the epicentre of teaching and the learning process, need to be adequately prepared and exposed to a continuous professional development and training programmes to enable them to be more productive to adapt to the changing world of teaching and the highly competitive and globalised economy.

Ayani (2011) in a study about teacher's professional development and quality assurance in Nigerian secondary schools revealed that teachers' qualifications, especially those attained through upgrading, improve their task performance and quality assurance in schools. However, this study did not cover promotions and quality assurance. Popescue-metroi et al. (2014) established that teachers' development in further training fosters quality assurance in classroom management procedures in technical higher education. Through this training, teachers acquire skills to manage classrooms effectively.

Mansueto et al. (2016) established that engaging teachers in professional development, especially in seminars, conferences, workshops and study leaves enhances and supports quality teaching in elearning. The study established that engagement informal professional development informs the development of e-learning, quality enhancement and assurance strategies. However, this study was on university professional development and quality assurance. The context is slightly different from that of teachers HRM professional development and quality assurance in a secondary school setting.

Szymenderski, Yagudina and Burenkova (2015) studied quality assurance in teaching in Russia and established that for quality teaching to be high in schools, teachers must be developed through giving them an opportunity to go back for refresher study courses. Mutiso (2013) emphasised that training is designed to provide employees with the skills needed in their present job.

\section{Promotions and Quality Assurance of Teachers}

Seniwoliba (2003) revealed that teachers' achievements and growth in their careers were highly responsible for quality teaching and the evaluation of learners. Once teachers' promotions are fairly distributed among teachers, their performance and satisfaction get enhanced leading to quality assurance. However, this study was not in a Ugandan context. In addition, Jain and Saakahi (2008) revealed that the promotion of employees on the job allows them to take up challenging tasks which enhances their performance and the quality of their work. Eyele (2014) stated that limited or lack of promotion opportunities affects educational outputs negatively. Gusdorf (2008) identified that promotion might be important in a stagnant economy where people have little chance of 
improving their lot by changing organisations. Their only opportunity for career growth would be through promotions that eventually enhances their productivity on the job. However, this was not an empirical study and was from a university environment on the effect of promotion on the quality of lecturers.

Azikuru et al. (2017) studied staffing and the quality of teaching in universities with the use of descriptive analysis and revealed that staff development, especially through promotions, statistically and significantly influence on the quality of teaching. However, in the suggested study quality of lecturers' services will involve publication, research and community outreaches. Meanwhile, Gentry and Stokes (2015) empirically revealed that promotions of staff motivated them to improve on their work outcomes. Professors in the university showed that their work efforts were highly effective in the areas of teaching, research and community service once offered promotions on the job. However, this study was a review of the literature but not an empirical one with quantitative techniques. Verdi and Quin (2010) studied promotion and the scholarship of teaching and learning and revealed that the promotion of staff enhanced teaching and research possibilities in institutions of higher learning. Still, most academic staff were revealed as working tirelessly to get promotions on the job.

\section{METHODOLOGY}

The study employed content analysis methods for reviewing mainly literature from journal articles and dissertations. This was based on the three main themes; i) off-job work station training; ii) on-job work station training; iii) promotions and quality teaching. Reviewed data was thus thematically analysed, especially based on how it portrayed the key aspects studied. The study area was in public secondary schools in the central region of Uganda. Human Capital Theory (Becker, 1964) states that employees should be retrained on their profession was used to guide the study. Quality assurance among teachers' preparations, teaching resources, assessment and methods of teaching, and infrastructures were reviewed. Time scope was taken between May 2018 to November 2018.

\section{FINDINGS ON THE REVIEWED LITERATURE}

The findings from the review revealed that off-job training, on-job training and promotions as human resource practices positively influenced the quality teaching processes by the teachers in secondary schools. This was through mentoring, conferences, workshops, study leaves, online learning, collaborative learning, peer reviews, collaborative teachings, supervisions, guidance and counselling and teachers' quality teaching enhancement. The training was identified as equipping teachers with required skills leading to high-quality teaching. Further, the findings revealed that after training there was a possibility for more competent teachers to be promoted, which also enhanced their teaching quality.

Rahman et al. (2011) studied the relationship between the training of teachers and the effectiveness of teaching. The study revealed that there was a significant correlation between teachers' in-service training and effective teaching. Seminars, workshops, coaching and mentoring organised on the job enhanced the performance of teachers significantly. Darling-Hammond et al. (2017) and Mohan and Chand (2017) emphasised that teachers in training programmes practice classroom routines and acquire more collaborative skills learning with others as peers. Sylvester (2015) in a study about human resource development in achieving quality assurance in postsecondary and higher education in Nigeria, revealed that human resource development through continuous off-job training offers job-related skills that enhance the quality of teaching.

Mansueto et al. (2016) established that engaging teachers in seminars, conferences, workshops and study leaves enhance and supports quality teaching and e-learning. The study established that engagement in formal professional development informs the improvement of quality enhancement and assurance strategies (Ayani, 2011). Jain and Saakahi (2008) revealed that the promotion of employees on the job allows them to take up challenging tasks that enhance the performance and quality of teaching activities. When secondary teachers are trained, mentored, attend seminars, workshops and conference, and promoted to the 
next level in their careers, their performance will be improved thus reducing the high rate of failures by students in secondary education. Gentry and Stokes (2015), empirically revealed that promotions of staff motivated them to improve on their work outcomes. Promotion of staff enhanced teaching and research possibilities (Verdi \& Quin, 2010). Mutiso (2013) emphasised that training is designed to promote employees with the skills needed in their present job.

\section{CONCLUSION AND RECOMMENDATION}

The paper reviewed the literature on teachers' quality assurance, the definition of theories, and the definition of the variables was provided. Human Capital Theory was used because it relates to the development of teachers in secondary schools. There was also a framework relating human resource practices and teacher's quality assurance. The findings suggest that human resource practise a critical aspect that all secondary school administrators should not neglect. Human resource practices positively influence teachers to be competent in enhancing quality teaching in secondary schools. On-job training of secondary school teachers enhances confidence and builds trust between the supervisees and supervisors in the class. Off-job and promotions among secondary school teachers enhance quality teaching among the teachers to practice their best in order to retain their current status.

Arriving at the findings, it is recommended that if teaching quality is enhanced in schools, more emphasis should be put on human resource professional development of teachers to mitigate the poor performance in secondary schools. Teachers should be encouraged and allowed to work together through collaborative teaching, peer reviews, mentoring one another and guiding and consulting one another. Further, a policy on staff off-job training, especially in areas where there is a need, should be designed and followed whenever teachers are to be offered with training opportunities. This will help in the reduction of the unfair provision of off-job training to teachers. There is a need for teachers to attend conferences, seminars and workshops so that they gain more experiences and also participate in designing practical programs for them through practice.
Intense supervision by the education district officials should be mandatory and given priority so that all planned continuous professional development plans are implemented at the right time. The schools' supervision tools designed by the Directorate of Education Standard (DES) are essential in ensuring that the teachers' performance is monitored and evaluated. This gives room to identify the gaps a teacher needs or lacks so that training or seminars are identified and implemented.

The Ministry of Education and Sports (MoES) should facilitate the training of skills gap among the teaching staff in secondary schools. Education partners and Non-Governmental Organisations that work hand in hand with the MoES should design programs that support teachers' professional development and career growth such that their knowledge, skills and attitudes in their careers are elevated, motivated and recognised in terms of performance and learning outcomes.

Finally, teachers should be promoted and transferred after the training. This will enhance the practising of the skills acquired leading to an improvement in the quality of teaching in secondary schools in the central region of Uganda. Teachers who are given the acting capacities like deputy headteachers or acting headteachers should be confirmed in the positions by the MoES so that they are not demoralised by reverting them to their original positions.

\section{REFERENCES}

Aslam H. D. (2013). Analysis of professional development practices for school teachers in Pakistan a comparative case study of public and private schools in Pakistan. International Journal of human studies, 3(4), 311-324.

Ayani, A. J. (2010). Teachers instructional task performance and principals' supervisory roles as correlates of quality assurance in secondary schools in Ondo State. Unpublished doctoral dissertation. Ile - ife, Nigeria: Obafami Awolowo University.

Ayani, A. J. (2011). Teacher professional development and quality assurance in Nigerian 
secondary schools. World Journal of Education, 1(2),143-149.

Azikuru, L. M. E., Onen, D. \& Ezati, B. A. (2017). Staffing and the quality of teaching in universities. European Journal of Educational Studies, 3(3), 21-36.

Balyejjusa, H. (2014). School contextual factors, talent management, teacher competency and student engagement in private secondary schools in Naddangira zone, Busiro North Wakiso District. Doctoral dissertation. Makerere University.

Becker, G. S. (1964). Human capital: A theoretical and empirical analysis, with special reference to education (Third Edition). University of Chicago Press.

Belash, O., Popov, M., Ryzhov, N., Ryaskov, Y., Shaposhnikov, S., \& Shestopalov, M. (2015). Research on University Education Quality Assurance: Methodology and Results of Stakeholders' Satisfaction Monitoring. Procedia-Social and Behavioral Sciences, 214, 344-358.

Chukwuma, E. T. C., \& Ofojebe, W. N. (2015). Utilisation of continuous professional development for academic staff effectiveness in the higher education sector in contemporary Nigeria. Journal of Emerging Trends in Educational Research and Policy Studies, 6(4), 306-314.

Darling-Hammond, L., Hyler, M. E., Gardner, M. (2017). Effective Teacher Professional Development. Palo Alto, CA: Learning Policy Institute.

Gentry, R., \& Stokes, D. (2015). Strategies for Professors Who Service the University to Earn Tenure and Promotion. Research in Higher Education Journal, 29.

Gusdorf, M. L. (2008). Recruitment and Selection: hiring the right person - A two-part learning module for undergraduate students. Alexandria, VA: Society for Human Resource Management.
Jain, N. G. \& Saakashi, M. (2008). Management theory and practice. India AITBS publishers

Kampala Capital City Authority (KCCA). (2017). Annual Review Report.

Kennedy, M. M. (2016). How does professional development improve teaching? Review of educational research, 86(4), 945-980.

Looney, J. \& Hannah, G. C. (2017). Quality assurance for school development. Guiding principles for policy development on quality assurance in school education. European Commission. Directorate-General for Education, Youth, Sport and Culture.

Ministry of Education and Sports (MoES). (2017). Directorate of Quality Assurance Annual report.

Mohan, P. P., Lingam, G. I., \& Chand, D. D. (2017). Teachers' perceptions of the impact of professional development on learning and teaching in a developing nation. Australian Journal of Teacher Education, 42(11), 18-33.

Msuya, O. W. (2016). Exploring levels of job satisfaction among teachers in public secondary schools in Tanzania. International Journal of Educational Administration and Policy Studies, 8(2), 9-16.

Mullins, L. J. (2010). Management and Organisational Behavior. Prentice-Hall.

Mutiso, M. C. (2013). Relationship between human resource management practices and quality service delivery in Kenyan public secondary schools in Taita Taveta County. Master Thesis. Kenyatta University.

Ogbodo, P. O. (2012) Manpower development in ensuring quality assurance in educational development in Nigeria. Research in Education, 18(1), 21-25.

Olufunke, I., \& Joseph, S. (2012). Quality assurance and effectiveness of Lagos State junior secondary schools. International Journal of Humanities and Social Science, 2(15), 166-170. 
Phillips, P. (2008). Professional development as a critical component of continuing teacher quality. Australian Journal of teacher education, 33(1), 1-11.

Raed, A. S., Teir, A. \& Zhang, R. Q. (2016). The current practices of human resource management in higher education institutions in Palestine. Journal of Human Resource Management and Labour Studies, 4(1), 65-83.

Rahman, F., Jumani, N.B., Akhtar, U., Chisthi, S.U.H. \& Ajmal, M. (2011). Relationship between training and effectiveness teaching centre for promoting ideas. International Journal of Behavioural and Social Sciences, 2(4), 150-160

Rose, J., \& Reynolds, D. (2006). Teachers' continuing professional development: A new approach. In 20th Annual World International Congress for Effectiveness and Improvement (pp. 219-240).

Sylvester, E. S. (2015). Imperatives for achieving quality assurance in higher education in Nigeria. Journal of Education and Social Research, 5(2), 171-176.

Szymenderski, P., Yugudina, L. \& Burenkova, O. (2015). The impact of an assurance system on the quality of teaching and learning-using the example of a university in Russia and one of the Universities in Germany. Higher Education Studies, 5(5), 15-25.

Verdi, I. and Quin, R. (2010). Promotion and scholarship of teaching and learning. The Curtin University of Technology. 